\title{
Integration of the Topic of Social Justice into High School Biology Curricula
}

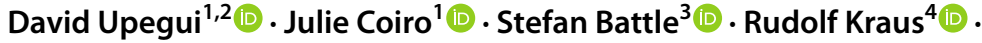 \\ David Fastovsky ${ }^{1,5}$ (iD
}

Accepted: 21 September 2021 / Published online: 11 October 2021

(C) The Author(s), under exclusive licence to Springer Nature B.V. 2021

\begin{abstract}
Systemic oppression includes inequitable education that historically does not fully prepare students for comprehensive participation in society. The tools of science education, however, uniquely enable students to explore social inequities as well as the natural world. Thus, a role of education can be to embed social justice in science curricula. Presented here are three case studies that investigate pedagogical methods used by experienced teachers to integrate social justice into upper level high-school biology curricula. Two separate semiconstructed interviews were conducted with participants, along with an analysis of their pedagogical materials. Two main themes are identified and explored: (1) delivery methods (pedagogy) and (2) biological science content. Storytelling and culturally responsive pedagogy were reported to be highly effective in engaging students; using these vehicles for delivery, social justice content can be seamlessly introduced alongside organic evolution. This embedded exploratory multiple-case study serves as an example of how science education can become a tool for student empowerment.
\end{abstract}

\section{Introduction}

Science is socially, politically, and functionally part of the power structure in society (Conner, 2005). If people are not scientifically literate, then they are un-empowered (National Research Council, 2012). Calabrese Barton (2003) writes that "[t]o know science-and to be deemed as one who knows science-is a uniquely powerful stance. Science education is political (p. 168)." Uniformly high-quality science education is the only way to implement a "sophisticated scientific understanding in which everyone can share" (Lewontin, 1991, p. 16).

David Upegui

upegui@uri.edu

Education Department, University of Rhode Island, Kingston, RI, USA

2 Chafee Social Science Center, Rm 705. 142 Flagg Road, Kingston, RI 02881, USA

3 School of Social Work, Rhode Island College, Providence, RI, USA

4 Educational Studies Department, Rhode Island College, Providence, RI, USA

5 Department of Geosciences, University of Rhode Island, Kingston, RI, USA 
Historical data, however, indicate racial inequity in the participation and success of Black, Indigenous, and People of Color (BIPOC) in science courses. For example, the College Board report (2019) indicates that Latinx and Black students are underrepresented in Advanced Placement (AP) biology classes and underperform in AP bio examinations. Educational inequity in general, and inequity in science education specifically, echoes the politics, economics, and ideology of our society (Morales-Doyle, 2017). Therefore, issues of equity in schools are inseparably enmeshed with broader issues of social justice (Duncan-Andrade \& Morrell, 2008). Current science education efforts like the Next Generation Science Standards (NGSS) provide a list of science tools which can be used by students to explore the world (e.g., asking questions, planning and carrying out investigations, analyzing and interpreting data, engaging in argument from evidence, obtaining, evaluating, and communicating information, etc.; as listed in the NGSS 2013), but fail to directly address social injustices as part of the standards.

This study begins with the premise that social justice topics can-even should-be included in a highly prescribed science curriculum such as AP biology and, in this case, that the optimal place within the curriculum to include these issues is within the unit on biological evolution. This is based upon the historical observation that justifications for racism are always ultimately biological, yet, the supposed biological differences between humans do not correspond to racial categories (Graves \& Goodman, 2021); that evolutionary biology is the study in which the origin and significance of biological diversity are addressed (Fuentes, 2021); and that high school is an almost ideal time for students to encounter and meaningfully consider these concepts (Jetha \& Segalowitz, 2012).

Ultimately, we conclude that there are multiple ways to incorporate social justice in the biology classroom, including using methods like storytelling tailored to our student demographic, and showing students that the tools of scientific discovery have direct applicability to societal issues.

\subsection{Theoretical Framework}

There is a growing academic literature which addresses methods for reaching historically disenfranchised students. Brazilian educator and philosopher Paulo Freire used the term conscientização (often translated as conscientization) to describe the process by which individuals are empowered to consider themselves capable of transforming their reality by addressing, and aiming to eliminate, oppression (Freire, 1970). According to Freire (1970), for individuals to gain conscientização, they must understand the historical and political circumstances that created the present inequitable social conditions. Although historically education has not been focused on such examinations (Freire \& Macedo, 1987; Giroux, 2004), the very process of understanding the evolution of historical inequities is a vehicle for empowerment (Morales-Doyle, 2017; see also Burton, 2003).

According to Dimick (2012), teachers who integrate social justice into their classes utilize curricula that are both academically rigorous and include counterhegemonic and empowering content and pedagogies. Similarly, Seiler and Gonsalves (2010) describe liberating science pedagogies as aiming to improve individual students' lives and opportunities, and the wider social reality. Such is the case with the concepts of "situated learning" (Lave and Wenger, 1991; Sadler, 2009) and "Culturally Responsive Teaching" (Hammond, 2015; Ladson-Billings, 1994). Gay (2002) makes a case that to improve the academic success of ethnically diverse students, culturally responsive teaching that emphasizes the students cultural and experiential filters must be utilized. Specifically, with science education, several 
authors have suggested engaging students in challenging social inequalities by using science teaching and learning that prioritizes social transformation (Barton 2003; Rodriguez, 1998; Morales-Doyle, 2017). When students are provided opportunities to engage in learning that aims to rectify social injustices, students become "empowered" (Dimick, 2012). In addition, Dimick (2012) describes three dimensions of student empowerment: social, political, and academic, all which are necessary for students to be challenged academically while also preparing them for the responsibilities of citizenship and the creation of a more just society.

Our own experiences, as well as those of other educators (see Morales-Doyle, 2017; Calabrese Barton, 2003; Dimick, 2016), suggest that the introduction of issues relating to social justice into a science course result in student empowerment and greater academic success. The blend of scientific concepts and social issues of direct relevance to student lives develops in them an intellectual traction that simply is not achieved by the exclusive presentation of biological concepts. But how should we merge these superficially disparate sets of ideas in a way that has meaning and significance for our students? MoralesDoyle (2017) offers the concept of "transformative intellectuals" which describes the type of students needed in a just society—those students that can demonstrate complex thinking about science and social justice issues writ large.

\subsection{Social Justice and Race}

The modern concept of social justice was codified in official statements and guidelines, including the United Nations' (1948) Universal Declaration of Human Rights (UDHR), which formally recognized "the equal and inalienable rights of all members of the human family." This publication was an acknowledgement that social justice interests in the modern world are a matter of international importance because we currently live in a closely interdependent world where injustices impact all peoples (United Nations, 2006). This emphasis is further substantiated in the more recent document Social Justice in an Open World: The Role of the United Nations (2006), which connects human rights to concepts of social and economic equity by identifying three critical domains of equality and equity, "equality of rights, equality of opportunities, and equity in living conditions" (pp. 15-16). Prilleltensky and Gonick (1996) describe social injustice as large-scale enactments of inequitable practices that can be understood from the macro-level of global economic and political structures to the micro-level of internalized psychological images of inferiority. For us, the expression "social justice," therefore, embodies the sense of equity and opportunity codified in the United Nations' UDHR and in the "Social Justice in an Open World." Its antithesis would be the kind of inequities, not to say iniquities, highlighted by Prilleltensky and Gonick (1996).

While in the USA systemic forces that feed social injustices can be based on many factors, for this project we focus on injustices based on race and ethnicity, which are connected to disparities in housing, material wealth, prisons, schools, and mortality/health, among other inequities (see Kendi, 2019). Of particular interest is the specious, but persistent idea of multiple biological races of humans, which presupposed that people from different "races" differ in meaningful ways (most infamously, in intellectual capacity; Saini, 2019). While modern genetics unambiguously falsifies this (Gould, 1996; Graves \& Goodman, 2021), by adulthood, experience suggests that the habits, prejudices, and beliefs of racism are deeply ingrained. It would seem that reversing the deleterious trajectory of societal racism must begin early. 


\subsection{Social Justice in Science Curricula}

Work by several researchers has demonstrated that science education can be a powerful tool to dismantle unjust social constructs. Donovan (2017) argues that a proper understanding of the meaning of genetic variation has significant consequences for racial prejudice. In that study, students that were taught biology with racist undertones such that people of different "races" were said to possess unique genetic homogeneity. Students so taught became less interested in socializing across racial lines and "less supportive of policies that reduce racial inequality in education (p. 379)," than those who were not. Donovan (2015) showed that students who have racist beliefs reinforced by biology curricula exhibited less support for educational policies that reduce racial inequalities since these must be immutably fixed by genes. Inadequate science instruction leads to racial animus in the students who receive it.

Similarly, work done by several other researchers demonstrates the importance of including students' values, identities, and interests in the science classroom in order to engage them in learning the material content and empowering them to become participants in scientific endeavors (see Dimick, 2016; Aikenhead, 2011; Basu \& Calabrese, 2010; Emdin, 2011; Olitsky \& Milne, 2012; Reiss, 2003). Freire (1970) goes a step further, explicitly stating that the goal of all education (including science education) is for students to become agents for social justice, challenging oppressive inequities and the political status quo (see also Giroux, 2004). Building on these ideas, Morales-Doyle (2015) offers a "Justice-Centered Science Pedagogy" theoretical framework in which students apply the logic of scientific thinking to identify the unfairness of social structures.

Here, our research question explores the experiences of AP biology teachers to learn how they incorporate social justice in their classes. The research question asks, "how have experienced teachers who self-identify as integrating social justice into their biology classes done so?".

\section{Methods}

Here, we present a multiple case study approach to explore mechanisms for traversing the relationship between social justice and a biological sciences curriculum. Since AP biology teachers cannot be detached from their respective contexts, a case study design enabled us to emphasize the importance of context for each participant (Yin, 2018). The data were collected using two semi-constructed interviews and gathering pedagogically relevant documents from the three teachers, manually developing a database matrix on the basis of the three cases. For one of the cases, an autoethnographic approach (Ellis et al., 2011; Starr, 2010) was used by the lead author to explore these topics in his own setting.

\subsection{Participants}

The research sample was a "purposeful sample" (Saldaña and Omasta, 2018) with "participants [who] were deliberately selected because they are most likely to provide insight into the phenomenon being investigated due to their position, experience, and/or identity markers" (p. 96). A preliminary online screener was used to check for eligibility of potential participants, targeting biology teachers who teach AP and non-AP bio classes and "feel like 
your teaching incorporates social justice." Targeted participants were solicited via personal email invitation and online communities including the "National AP Biology Teachers" Facebook closed group, and The College Board's AP Teacher Community group.

We sought three teachers who maximized the breadth of the sample with regard to race and the socio-economic conditions of their schools and students. An additional selection criterion was the teachers' abilities to communicate how they engage with social justice in their biology classrooms. Subsequently, two interviews for each teacher were scheduled, conducted, and recorded. The interviews explored not only the details of the teaching strategies used (see Supplement, Appendix A), but also documented how these teachers engaged and interacted with the larger learning communities where they teach biology.

\subsection{Informed Consent and Confidentiality}

Participation by the teachers was voluntary with the option withdraw at any time. All participants had a right to review their data and study findings. Pseudonyms were used to protect teachers' identities. Teacher participants completed consent forms prior to data collection. The forms were approved by the Institutional Review Board of the University of Rhode Island, and all data were stored on a password-protected computer.

\subsection{Research Design: Case Studies}

Ultimately, the three cases comprised the "embedded, exploratory multiple-case study" of Yin (2018, p. 96), in which the combination of data from the three case studies generated greater analytic power than would otherwise independently arise from single independent cases. Following Stake (2006), this study isolated similarities and differences among the cases to better characterize the embedding of social justice in biology curricula.

The interviews of Teachers 1 and 3 were conducted by the lead author (Teacher 2). The autoethnographic interviews were conducted by the lead author's nephew, a doctoral candidate in sociology at Brown University. This enabled a type of member-checking (Forber-Pratt, 2015), where we could ensure that the information was legitimate, reliable, and trustworthy by asking (a) Does it make sense? (b) Does it make sense to someone who knows me? (c) Does it make sense to someone in my family? (d) Does it make sense to an academic?

All three participants completed two separate interviews and answered the same questions in the same order. Video conferencing was utilized and subsequently, audio was transcribed. A semi-structured format enabled participants' responses to direct the flow of the interview (see Saldaña and Omasta, 2018). For each participant, the two interviews were separated by about 1 week to provide time to reflect on the ideas covered in the interviews as well as to enable teachers to find and prepare the pedagogical materials which were discussed in the second interview.

To triangulate the data collected during the rest of the case studies data collection components (Merriam, 1992), we requested pedagogical artifacts from the participants (see Table 1). These materials included syllabi, lesson plans, instructional resources, and student work products (see Supplement, Appendix B), which, among other things, helped track the timing/placement of the introduction of social justice within the biological sciences curriculum (see Patton, 2015). 
Table 1 Inventory of pedagogical materials provided by each teacher

\begin{tabular}{|c|c|c|}
\hline Teacher case 1 & Autoethnography case 2 & Teacher case 3 \\
\hline Class materials: & Class materials: & Class materials: \\
\hline AP bio class syllabus & $\begin{array}{l}\text { AP bio class syllabi (w/ social } \\
\text { justice objectives) } \\
\text { AP covenant } \\
\text { Welcome to class } \\
\text { List of stories }\end{array}$ & $\begin{array}{l}\text { AP bio class syllabus } \\
\text { AP bio contract } \\
\text { AP bio curriculum map } \\
\text { AP bio summer assignment }\end{array}$ \\
\hline Lessons: & Lessons: & Lessons: \\
\hline $\begin{array}{l}\text { Evolution } \\
\text { Skin pigmentation patterns } \\
\text { Extreme weather events } \\
\text { Climate conditions \& epidemiology } \\
\text { Disruption of migration } \\
\text { Effects of climate change }\end{array}$ & $\begin{array}{l}\text { Migration lesson } \\
\text { Gender/sex } \\
\text { EPA and current administration }\end{array}$ & $\begin{array}{l}\text { Surviving winter in the dust bowl } \\
\text { (food chains and trophic levels) } \\
\text { October field experience: investi- } \\
\text { gating artifacts }\end{array}$ \\
\hline Student sample work: & Student sample work: & \\
\hline Extreme weather events & Migration essays & \\
\hline \multicolumn{3}{|l|}{$\begin{array}{l}\text { Climate conditions \& epidemiology } \\
\text { Disruption of migration }\end{array}$} \\
\hline & Other: & Other: \\
\hline & $\begin{array}{l}\text { Yearbook entries } \\
\text { Student notes }\end{array}$ & $\begin{array}{l}\text { Teaching Tolerance Social Justice } \\
\text { Standards }\end{array}$ \\
\hline
\end{tabular}

\subsubsection{First author involvement}

An autoethnographic approach enabled the first author to deepen the richness of the analysis by participating in the research. Aside from being treated as one of the cases, completing two interviews, and providing pedagogically relevant materials, the first author was able to document his personal experiences as a Latinx, a low-income student and subsequently a science teacher at his alma mater; that is, a school in which the shared experiences of most students matched his. This personal history enriched the study and complemented the data from the other two participants.

Merriam (1992) proposes that a variety of written, visual, and physical material can shed light since these materials result from human activity recorded over time. According to Merriam's (1992) definition, most of the materials analyzed here were primary documents. The totality of the pedagogical materials collected and analyzed, supported, and enabled us to flesh out the interviews by facilitating data convergence and trustworthiness of data interpretation.

Some secondary documents were also used (e.g., Teaching Tolerance Standards from the Southern Poverty Law Center, 2020) to explore the themes that were established. The documents were compared for confirmatory or contradictory information to illuminate the cases. The content analysis utilized here was the constant-comparative form of document analysis (Bogdan \& Biklen, 1998) where we searched for themes that recur in a variety of documents leading to categories that confirmed general themes generated from the interviews. Table 1 lists the materials shared by each teacher. 


\subsection{Analyses}

To establish the trustworthiness of the results, member-checking and peer review procedures were followed (Creswell, 2014). All participants were sent a document that summarized the major themes identified in the analysis, and asked to review it, to provide feedback on any interpretations that they felt were inaccurate or incomplete (Fraenkel et al., 2012; Creswell, 2014). Furthermore, two professional colleagues, one with a PhD in Education and the other with M.S. degrees in both Public Policy and Sociology, reviewed the documents and provided feedback on our interpretation of the data. Both reviewers read through the transcripts and pedagogical documents to verify the coding and clustering.

The general analytic strategy used was inductive (after Yin, 2018). We created a categorical matrix that allowed us to juxtapose the data from the different interviews and identify shared themes within the matrix. To increase trustworthiness of the data, each of the interviews was revisited and new labels were created for shared viewpoints not considered significant the first time around. This iterative effort enabled the verification of the meaningfulness and accuracy of the categories used. To expound the information gathered using semi-constructed interviews in this exploratory project, a multivocal three-column narrative style was used (see Supplement, Appendix A).

\section{Results}

\subsection{The Three Cases}

Below, the three case studies are individually defined by (a) characteristics of the teacher, (b) the municipality where they teach, (c) the school where they teach, and (d) corresponding key data from the interviews and the pedagogical materials. Potential identifiers of the participants have been removed. Further detailed data are listed in the appendixes.

\subsubsection{Case 1}

Teacher 1: The participant described herself as a white female. This teacher reports serving students from underrepresented populations. This teacher has a doctorate in education and has taught biology for 10 years.

1 Location 1: High School 1 is an urban school located in a major city of the USA. The last available reported Census data for the city (2018) show around one-quarter of the population is under the age of 18; an equal percentage lives below the poverty level.

2 School 1: High School 1 is a coeducational college preparatory school. The student body is selected on the basis of a rigorous entrance examination (High School Placement Test and Naglieri Non-Verbal Test) as well as superior academic achievement. It is the only public "test-to-enroll" school in its city. This school has an almost nonexistent population of students classified as "English Language Learners" (ELL; less than $0.5 \%$ of students), while other high schools in the district have more than $50 \%$ of students defined as ELL. However, these numbers do not capture any formally classified ELL student that, due to language gains, no longer receives ELL support. In 2019, approximately 
three-quarters of students from this school were classified as recipients of free/reduced lunch and the school reported serving over 1000 students.

3 Key data. Direct quotes from Teacher 1:

Students need to know about how science works and that there is that intersection and that science can be used. Science can be done in a way that hurts people or can be used improperly in a way that oppresses people. And I think it's a tragedy that's not specifically part of the AP curriculum. My goal for students is for them to gain a heightened level of scientific literacy... [understanding] what science is and how it works. But also, how it's been used for the positive and for negative. Science exists in a context and if we don't have the context the science lacks meaning. Science has been used, as have many other fields, as a tool of oppression. I think as a bio teacher it is important to call attention to that. It is important to call out how Linnaeus tried to argue that different races of humans make up different species. It's important to talk about things and leave my class more 'woke'. It's also important to talk about it in a science context and what I mean by that, in terms of scientific research, we have done horrible things to marginalize populations through science.

Around evolution and the Linnaeus piece, there was a place to talk about it [racism] in class and so to me it makes sense, and it makes sense in this climate because this current political climate is dangerous to our students of color and it is equally dangerous to our white students. The debate whether humans were actually different species and then what that means in a larger context because people start to be able to have those conversations and so the science is interwoven. We talked about evolution in the environment and that's when we do the race thing, contrasting social and biological concepts of race. Students show great interest in the exploration of social justice with evolution, they always want to talk about climate change and they truthfully love evolution. They really and truly love Evolution... addressing issues of racism addressing issues related to poverty and addressing issues related to gender is something we can do because those are conversations that are happening.

Key data from the pedagogical materials. These are guiding questions for the unit focused on evolutionary theory:

A. "Where have you been exposed to inaccurate representations of evolution? What impacts do you think that these inaccurate representations of evolution have on an individual's understanding of evolutionary theory?

B. How has evolutionary theory been misused to oppress groups of people based on race, gender, and other factors? How can understanding evolutionary theory help to mitigate oppression?

C. How did human skin color evolve? What evolutionary pressures impact skin color?

D. How has evolutionary theory been misused to oppress groups of people based on race, gender, and other factors? How can understanding evolutionary theory help to mitigate oppression? 


\subsubsection{Case 2}

Teacher 2: Teacher 2 has taught AP biology for the last 9 years at his alma mater. He is one of the seven BIPOC teachers in this school [out of 70 teachers] which serves mostly racially minoritized students. As a graduate of the school and a Latinx person, he has many direct and visible connections to the students. Case 2 is an autoethnography and records the responses of the lead author of this study.

1 Location 2: High School 2 is in an urban setting in a small and densely populated city in the USA. The last available reported Census data for the city (2018) shows approximately 20,000 residents with over one-quarter of persons under the age of 18. The number of persons in poverty is reported around 33\%. Teacher 2 presents a reported population per square mile of over $16,000 / \mathrm{mi}^{2}$, compared with less than $3,500 / \mathrm{mi}^{2}$ for Case 1 and under $10,000 / \mathrm{mi}^{2}$ for Case 3 .

2 School 2: High School 2 is the only traditional public high school in this city. This high school has the highest percentage of Latinx in the state and serves the most low-income community in the state. Reportedly, $100 \%$ of its students are classified free/reduced lunch recipients. In 2019, the school reported serving over 800 students.

3 Key data. Direct quotes from Teacher 2:

People historically have considered science to be exclusively about the experimentation and observation of the natural world and in that sense, they don't see it as political; they don't see the necessity of introducing social justice into the curriculum. And I think that's a mistake. I think it's an opportunity that we're given and critical thinking and other transportable skills that are learned while learning biology can be applied to a variety of situations including social justice. There are places in the curriculum, and I think that part of our job is to find out where we can talk about injustice and how we are preparing the students in front of us to change that. I have a couple of assignments that specifically target students' ideas about social justice. And one of them is about migration and I use some of the rhetoric that Trump and his administration have put forth about immigrants and the way that he has expressed his dislike of immigrants; particularly of brown and black immigrants... students consider migration of other animals besides humans, for them to understand and appreciate the fact that migration is a natural biological phenomenon. Then they look into migratory patterns of early humans... then consider what migration into the United States looked like, some of it forced through slavery and some of it through the appropriation of territories. I want them to understand that these things are not random and that they were in fact, the result of a system that's been created and that oppresses some over others. Education is about empowerment and students need to appreciate what's happening to them and how it happens to them.

If we're talking about evolution, I'm going to bring up the idea that white people and particularly white men had used evolutionary theory to make themselves seem more capable, more intelligent, sort of the culmination of evolutionary forces and in that way if you make one race or one group of people superior then immediately, you're making others inferior. I want my students to understand why it is that they and I, are considered to be inferior based on flawed science. 
Key data from the pedagogical materials. Quote from a Black student (non-immigrant) for the migration project assignment:

Humans have always migrated, that's how we've developed as the species we are today. To say that immigration is bad, is to say that our nature as a species is bad. Even so there is still a huge debate that continues to accelerate, and probably will continue to do so as long as we have people from different backgrounds in our country. But that in itself is what makes America great and the human species great. The fact is that we need to have discussions about topics such as immigration so that the world can be a better place.

\subsubsection{Case 3}

(a) Teacher 3: Teacher 3 self-describes as "White lady of non-Hispanic origin," and holds a doctorate in the biological sciences and has taught biology for the last 10 years. This participant reported being assigned female at birth and self-identifies as genderqueer, using she/her/hers pronouns.

1 Location 3: High School 3 is located in a small suburban area, described by the teacher as a "University town." The last available reported Census data (2018) showed around 85,000 residents with around $10 \%$ of persons under the age of 18 .

2 School 3: High School 3 is a highly rated public high school, with the largest high school student body in the school district. The school's website describes high levels of SAT and AP success for their students, since they outperform schools similar in size both in scores and in the number of students taking the SAT and AP courses. The teacher reported teaching a high percentage of people who identify as female, a high percentage of trans/nonbinary students in AP Bio, as well as many "Questbridge" students (a program that works with "the nation's most exceptional, low-income youth with leading colleges and opportunities... to increase the percentage of talented low-income students attending) (Questbridge 2020). In 2019, the percent of students from this school classified as free/reduced lunch recipients is around $25 \%$. The school reported serving over 1500 students.

3 Some key direct quotes from Teacher 3 include:

I want my students to walk away with what I consider to be a set of basic biology ideas for citizenship. I want them to think that you can do the same type of thinking that scientists do. During our unit about genomics, a lesson series about genomics that is centered about race and whether people of race the different races are different have different genes, this kid felt included. In an assignment they wrote letters to authors and so many of the letters were about social topics and that might not just be my class-it might be the social discourse right now, about who matters. That's the really interesting thing about having this conversation in science as opposed to conversations in social studies; in social studies the conversation often comes down to whose story matters, who lives, who dies, who tells her story, right? In bio the question comes down to how do we know? What do we know about the world? And how do we know it? And that's a science question! 
Table 2 Noteworthy demographic data for all three cases (for the protection of participants, numbers have been rounded)

\begin{tabular}{llll}
\hline & Case 1 & $\begin{array}{l}\text { Case 2 } \\
\text { (autoethnog- } \\
\text { raphy) }\end{array}$ & Case 3 \\
\hline Type of school & Public (test-in) & Public & Public \\
$\%$ White only city & $34 \%$ & $21 \%$ & $80 \%$ \\
$\%$ White only school & $25 \%$ & $10 \%$ & $85 \%$ \\
$\%$ White only AP bio & $40 \%$ & $7 \%$ & $75 \%$ \\
$\%$ Free/reduced lunch & $\sim 75 \%$ & $\sim 100 \%$ & $\sim 25 \%$ \\
Enrollment in school & $>1000$ & $>800$ & $>1600$ \\
No. of years teaching AP & 10 & 9 & 10 \\
Race of teacher & White & Latinx & White \\
\hline
\end{tabular}

Evolution is used to cover social justice standards, they already know they're going to learn about evolution... phenotypes and genotypes changing over time... I included a teaching tolerance standard about the teaching tolerance anti-bias framework and included one question [relating evolution and racism]. So why teach social justice to my bio students? Because they need those stories. They need stories of people righting wrongs. They need stories of people making mistakes as success. They need stories of altering their worldview about who counts and what we think we know about different groups.

Key data from the pedagogical materials. Quote from Teacher 3's "AP Bio contract:"

Together, we'll explore what it means to work as scientists: asking questions, collecting and analyzing data, making and revising explanations and models, practicing critical thinking, and participating in the ongoing conversation that is science. Finally, being a scientist involves working in ways that are respectful, responsible, and reflective.

A summary of the notable demographic data for the three cases is provided in Table 2.

\section{Analysis}

\subsection{Congruencies}

All teachers spoke of the opportunities biology classes offer that are uniquely connected to social justice, in this case, an advanced biology class such as AP biology. When asked about the major goals of the AP bio class, all teachers voiced their reliance on explicitly teaching students "how science works." Another congruent theme was the idea of students being "learners" of more than just content material. For example, Teacher 1 used the term "woke" meaning that students are made aware that there is no biological basis for social inequities, despite a pernicious history of oppressive claims to the contrary. For all three teachers, there is an intrinsic relationship between the science content covered in biology and social justice; and, when students learn both they are empowered and enfranchised. When students understand that biology does not validate racists' views about different human groups, students in turn can begin to ask questions about how the socially constructed concept of race has been utilized to oppress some people. 
All teachers mentioned that some of the "aha" moments in their classes include the expansion of the content covered in the classes to their personal lives and/or greater society. Here, the teachers see students using science as a tool of exploration and empowerment (see Aikenhead, 2011). Other similarities included the teacher's role in helping students understand social injustices. Past social injustices such as eugenics and race-based slavery are the nexus of the relationship between social justice and biology, and the exploratory process provides students with insights into why the two have been intertwined. Teachers made connections between the importance of teaching about past injustices and ways in which segments of society have benefited from oppressing others, including through the misuse of science. For example, Teacher 3 had students consider the intersection between environment and social justice leads to racially charged situations such as the social setting for the Flint (Michigan) lead and water pollution. Similarly, Teacher 2 reported the impact of a liberating science lesson (sensu Seiler \& Gonsalves, 2010) that addressed migration and showed that individually and collectively students utilized the opportunities afforded in the lesson to explore their lives and the wider social reality.

When questioned about why there is a need for social justice, a consistent theme addressed by all three teachers was the social influences on science and the selective application of scientific knowledge to benefit specific groups of people. So, for example all three teachers brought up specific examples of abuses committed by the use of science. Such is the case with the Tuskegee syphilis study (stated by Teachers 1 and 2), the Puerto Rico cancer research by Cornelius P. Rhoads (stated by Teacher 2), Henrietta Lacks and HeLa cells (stated by all teachers), and the current administration's denial of climate change data (stated by all teachers).

All teachers strongly advocated the use of stories. Stories presented in the classrooms by teachers in this study include topics of injustices and although at first glance may seem disjointed, there is a common thread in that these all provided points of references that were useful to students. Stories included Henrietta Lacks (1920-1951), whose cancer cells, used without her consent, though the source of perhaps the single most important cell lines in medical research (the HeLa cell line), received no compensation; Lynn Margulis (1938-2011), the originator of the then radical endosymbiotic theory for the origin of eukaryotic cells, who had to fight to be published; Rosalind Franklin (1920-1958), whose contribution to the discovery of the structure of DNA arguably should have earned her a spot in the shared Nobel Prize for Physiology or Medicine in 1962; National Climate Data Center scientist Deke Arndt (1972-), who tells the story of his extended family having survived the Dust Bowl in the 1930s and its relationship to his own interest in climate science; and Carl Linnaeus (1707-1778), whose still-used scientific classification system reflected his and his contemporaries' shocking (by modern standards) racist views. Each of these stories likely resonates for students because it treats individuals who clawed their way to success despite marginalization or, in Linnaeus' case, the blatant racist viewpoints he espoused have had long-lasting impacts including the legal enslavement of people for over 250 years and the marginalization of people who he promoted as less than fully human. Storytelling is more than just a way of teaching science history, as it is intended to help students be critical of scientists and their work. Moreover, stories can serve as avenues that tap into students' compassion and curiosity and potentially help them to see themselves as scientists by developing an interest in science as a human endeavor.

A clear commonality for all three teachers was the immediacy of the Trump presidency, which has highlighted many issues pertinent to this study. President Trump and his administration expressed, both verbally and by policy, indifference to and disdain for racial minorities as well as science (Petrella \& Hasan Loggins, 2017; Tollefson, 2020). 
Data analyzed by the Brookings Institute demonstrate that anti-immigrant sentiment, racism, and sexism were most strongly linked to support for Trump (Williamson \& Gelfand, 2019). With so long and well-documented a history of presidential speech and actions as dismissive of scientific expertise, divisive, and racially charged (Graham et al., 2019), these three teachers all tapped the destructive energy emanating from this administration to inject social justice into science classes.

Lastly, all three teachers agreed that there is greater flexibility in terms of time, standards/objectives, and testing with non-AP science classes. However, there are some important opportunities that AP bio classes uniquely offer, including the maturity and commitment of the students, and the ability to focus on certain aspects of biology; namely, genetics, ecology, and evolution. Finally, all participants shared their enthusiasm for exploring social justice throughout the year, including after the AP exam.

\subsection{Incongruencies}

The teachers' concerns about incorporating social justice in their biology classrooms were revealing. Teacher 2 , a teacher of color, responded to the potential offense that few white students $(\sim 10 \%)$ and the bulk of teachers ( 90\% white) might feel. On the other hand, the other two teachers, both white females with doctorates, did not express the same type of hesitation about offending white people; although Teacher 1 mentioned reluctance toward her building administrators, but not related to race. Moreover, Teacher 3 also reiterated that because of her academic credentials and her success with the class, she feels less susceptible to challenge.

Turning to providing guidance for teachers who have not taught social justice, there were some clear differences in the responses. Teachers 1 and 3 both alluded to being open about their race (white) with students. Hand in hand with this was creating a safe space for students to discuss racially charged social justice issues. Moreover, all teachers affirmed that it may take effort to find places within the biology curriculum where social justice can be highlighted, and that this is a necessary task that must be undertaken.

Incongruencies were also found between the teachers when comparing the methods used for introducing social justice ideas into the bio classrooms. When asked specifics about how social justice topics were introduced in the bio classes, it became apparent that there are some units where social justice is easier to incorporate. These units include "genetics," where the concepts of race can be discussed and "evolution" where concepts of common ancestry and natural selection are covered. Teacher 1 targets specific parts of the curriculum, while Teachers 2 and 3 use a variety of lessons that interweave social justice throughout the year, even in those units that focus on cell and molecular biology.

Although many of the lessons described in the cases had objectives that connect historical context and emphasized how scientific reasoning can challenge erroneous social constructs as student develop a critical cultural lens, responses diverged dramatically when asked if the biological learning objectives were distinct from those of social justice. For fear of being misunderstood, Teacher 1 does not write down social justice objectives but verbally tells students that they will be covering social justice topics. The approach of Teacher 2 is more formalized, in that a series of literature-based social justice standards (Thompson et al., 2014), are initially read to the class, and embedded throughout the year. Teacher 3 uses a published set of objectives, the Social Justice Standards from the Teaching Tolerance Program (Southern Poverty Law Center, 2020). This teacher lists these standards in her syllabus and goes over these with her students. 


\subsection{Significant Themes}

Several meaningful and significant themes arose after analyzing the case studies. Two main categories of themes were identified: (a) Delivery and (b) Content.

\section{Delivery (Pedagogy/Culture of the Classroom):}

Perhaps the most significant pedagogical tool brought up by all three teachers is that of storytelling. This is not surprising since there is ample evidence from the literature that describes the benefits of telling stories in the science classroom, whether the researchers' struggles inspire (Lin-Siegler et al., 2017), facilitate information processing (Engel et al., 2018), or simply engage and entertain (Reid-Smith, 2013). Storytelling is a well-known pedagogical technique, which has been documented by researchers like Klassen (2009), Hadzigeorgiou (2016), and Calabrese Barton (2003) who writes that "[S]tories are powerful research tools. They provide us with a picture of real people in real situations, struggling with real problems. They banish the indifference often generated by samples, treatments, and faceless subjects. They invite us to speculate on what might be changed and with what effect" (p. 7). Saini (2019, p. 126) puts it succinctly: "[S]cience is not enough to forge identity. We also need stories...".

Our current news stories, including the global pandemic caused by COVID-19, and the anti-racist activism in the wake of police killings of unarmed black people, as well as those mentioned above, serve our students as they highlight the relationships between science and social justice. Given that historical data that show an underrepresentation of BIPOC in science, we can infer that BIPOC students are generally not getting the science education they need to fully participate in scientific endeavors and/or influence the policymakers which have been profoundly unresponsive to the needs of their communities. For instance, we know that climate change and COVID-19 disproportionately affect marginalized populations (Lakhani, 2019). Yet, researchers, epidemiologists, virologists, and climate scientists tasked with studying these issues and proposing policies to remediate them are profoundly unrepresentative of those populations (500 Women Scientists Leadership, 2020). Seen in this light, science education is pivotal for the well-being of our nation including those individuals who belong to groups that have historically been left out of science.

Aside from storytelling, another closely connected theme in the case studies is the applicability of material to the students. As mentioned earlier, all teachers in the case studies mentioned the importance of making science "real" to students by providing context. This "realization" includes the explicit teaching of historical accounts that include anecdotes where science has been used as an oppressive tool. Rudge et al. (2014) argue that the history of science should be an integral part of the science classroom. These researchers used a historically based unit to improve the appreciation and understanding of the nature of science, which they view as a fundamental component of science literacy.

The teachers in all three cases worked to ensure that students feel that they are valued and respected, and that a way to convey this is to situate the learning in the students' world. This approach accords with Freire's (1970) idea of critical consciousness, where rather than the teacher, the students are at the center of the classroom. Much of the approach described by the three teachers also resembles the "Culturally Responsive Teaching" originally described by Ladson-Billings (1994) and more recently advocated by Hammond (2015). This pedagogical framework recognizes the importance of including students' cultural references in all aspects of learning, and student-centered instruction enables for 
learning within the context of culture where the teacher serves as facilitator. Using this framework helps teachers to create environments, curricula, and instructional methods that validate and reflect the diversity, identities, and experiences of all students, which in turn has positive impacts on the students and raises the level of academic rigor (Hammond, 2015). Interestingly, Teacher 3 noted that well-intentioned white teachers need to check "impulses to be white superheroes." She said, "I am not trying to solve everybody's problems, but I am happy that I can be a conduit for people to bring problems that I can then help them find ways to address."

Lave and Wenger (1991) and Sadler (2009), used the term "situated learning" to describe the fact that knowing, and learning do not transpire independent of context. They argue that a focus on socio-scientific issues and the development of socio-scientific discourse promote scientific literacy. It is therefore not surprising that all three teachers emphasized group-group and student-student interactions, and socio-scientific discussion.

\section{Biology (content)}

It may seem counter-intuitive to think that there would be significant variation in content covered among professionals who teach a highly prescribed curriculum such as AP bio which is provided by the College Board. But in fact, there is latitude and selection of certain foci which may prove to be the most beneficial for teaching social justice. All three teachers found pedagogical vehicles to highlight content which they felt was important for social justice. In addition, all three teachers covered topics such as human races (including the Howard Hughes Medical Institute materials for skin color; HHMI, 2020), gender and sex, who does science, and the state of the environment and the EPA as a guarantor of it.

One broadly shared content area was "how science works." All three teachers value authentic science practices where students use critical analysis and data to support their conclusions, much the same way that scientists do. This aligns with the NGSS as well as the College Board's AP biology curriculum. Teacher 3 noted, "the tools of science are the tools of liberation. When we ask students to do these practices of science like argumentation or communication or data analysis, it turns out that they are the identical tools that people have to develop individually and collectively to work against oppression and to dismantle oppressive systems. It's kind of a two-for-one, you're building students' scientific literacy and capacity but you're also giving them tools that they can directly apply to other problems or issues. Science is centered on data and we can provide experiences for students centered on data and as we grow more skilled begin to include data sets that bring up these really important ideas of injustice as well as find ways for action." Thus, students not only gain content knowledge but more importantly, realize that the natural world is understandable by using the tools of science (e.g., Questions and Methods, Representing and Describing Data, and Argumentation; as described in the AP Biology CED 2019). All three teachers shared the recognition that skills developed to investigate the natural world are the same skills needed to investigate the socially constructed world, aligning with ideas from Freire (1970), Dimick (2016), and Morales-Doyle (2017).

Perhaps the most important content concept, and one not fully borne by relevant literature was the utilization of evolutionary theory. The three teachers placed enthusiastic emphasis on teaching "evolution, race and ethnicity," because it allows for the direct and explicit deconstruction of racial concepts. Since all three teachers brought up evolution as part of their approach for covering social justice in their biology classrooms, this begs further exploration. The importance of the topic of evolution is highlighted in the Life Science 
strands of the NGSS since it makes up one of the five "topics" (National Research Council, 2012) and for the AP bio curriculum it is one out of the four "Big Ideas" (College Board 2019). Therefore, it is well understood that evolution must be presented, and assessed as part of biology class.

Evolutionary theory has long been understood to unify the biological sciences as a cohesive scientific discipline; of relevance here, the facts of evolution strongly refute established racist hierarchies. The teaching of evolutionary theory leading to social justice therefore works at the high school level both in terms of science education and personal empowerment. Hence, social justice ought to be taught along with evolutionary biology, or the subject is getting an incomplete treatment; an outcome of particular consequence to BIPOC students, not to say all students. No other science can make that claim, so it is evolutionary theory that is best suited to unite biology and to underpin social justice.

\section{Limitations}

This study included a limited number of individuals, and importantly, only included individuals who self-identified as integrating social justice in their AP biology classes. Followup research could also include teachers who have a desire to conduct this type of work but have found challenges to implementing their ideas. Finally, an obvious next step in refining and broadening this approach would be to interview the students themselves, asking them what resonated for them, and how they feel that exposure to these subjects changed (if at all) their awareness of themselves and their world.

It is important to consider the positionality of the researchers in this study. In this project, the first author served as the main data collection and data analysis instrument, as well as one of the participants. While he maintained awareness of potential influence as the researcher and strove in every respect for absolute neutrality, his deeply felt advocacy of these issues may have influenced his choices in ways in which neither he, nor the unassociated professional colleagues, nor the participants themselves, were aware. As with all research projects involving humans and their positionality, the methods used in this study have inherent limitations that we addressed using procedures designed to increase the trustworthiness of the data (see Yin, 2018; Stake, 2006; Merriam, 2009).

\section{Conclusion}

This multiple case study project explores ways in which biology teachers incorporate social justice into an already-packed curriculum, such as is the case with AP bio, in which the curriculum is guided by standards established by the College Board. As the data from the current study suggest, there are many ways to incorporate social justice in the biology classroom. Storytelling is perhaps the most consistent and powerful tool, particularly with the types of stories that allow students to either see injustices done to which they can connect, or unscientific conclusions reached with obviously destructive consequences. In the present study, we reaffirm that an optimal, but not exclusive, place for the introduction of these ideas is with the evolution unit of study. Parallel to learning about organic evolution and its explicit conclusions about the diversity and unity of life, students can begin to appreciate that external phenotypical variations cannot account for the social injustices in our world. More broadly, the explicit teaching of what science actually is, and how it 
works - an endeavor that values transparency and integrity over prejudice and belief-as well as a natural pedagogical connection between social justice and science in the biology curriculum. The experiences shared by the participants in this multiple case study suggest that science generally, and evolutionary biology in particular, can be powerful weapons in students' arsenals to challenge social injustice.

Supplementary Information The online version contains supplementary material available at https://doi. org/10.1007/s11191-021-00287-y.

Acknowledgements Thanks are due to Jonathon Acosta for conducting the interviews with the lead author. We also want to thank several people who read over parts of this text, Dr. Diane S. Pimentel, Carrie Appel, and Drs. Richard Song and Beth Pinheiro. We are thankful to Dr. Daniel Morales-Doyle for his inspiring work and guidance. Lastly, for their patience, generosity, and time, we want to thank the participants who are motivating teachers and supportive professionals.

\section{Declarations}

Conflict of Interest The authors declare that they have no conflict of interest.

\section{References}

500 Women Scientists Leadership. (2020, June 6). Silence Is Never Neutral; Neither Is Science. Retrieved June 10, 2020, from https://blogs.scientificamerican.com/voices/silence-is-never-neutral-neither-isscience/

Aikenhead, D. (2011). Towards a cultural view on quality science teaching. In D. Corrigan, J. Dillon, \& R. Gunstone (Eds.), The professional knowledge base of science teaching (pp. 107-127). Springer.

AP Data - Research - College Board. (2019, October 7). Retrieved September 7, 2020, from https://resea rch.collegeboard.org/programs/ap/data

Basu, S. J., \& Calabrese, B. A. (2010). A Researcher-student-teacher model for democratic science pedagogy: Connections to community, shared authority, and critical science agency. Equity \& Excellence in Education, 43(1), 72-87.

Bogdan, R. C., \& Biklen, S. K. (1998). Qualitative research in education: An introduction to theory and methods (3rd ed.). Allyn \& Bacon.

Burton, L. (Ed.). (2003). Which way social justice in mathematics education. Praeger.

Calabrese Barton, A. (2003). Teaching science for social justice. Teachers College Press.

College Board AP® BIOLOGY Course and Exam Description (Revised 2019) https://apcentral.collegeboa rd.org/pdf/ap-biology-course-and-exam-description-0.pdf?course=ap-biology

Conner, C. (2005). A people's history of science: Miners, midwives, and "low mechanicks". New York: National Books.

Dimick, A. S. (2012). Student empowerment in an environmental science classroom: Toward a framework for social justice science education. Science Education, 96(6), 990-1012. https://doi.org/10.1002/sce. 21035

Dimick, A. S. (2016). Student empowerment in an environmental science classroom: Toward a framework for social justice science education. Science Education, 96(6), 990-1012.

Creswell, J. W. (2014). Research Design: Qualitative, Quantitative and Mixed Methods Approaches (4th ed.). Thousand Oaks, CA: Sage.

Donovan, B. (2015). Reclaiming race as a topic of the U.S. biology textbook curriculum. Science Education, 99(6), 1092-1117.

Donovan, B. M. (2017). Learned inequality: Racial labels in the biology curriculum can affect the development of racial prejudice. Journal of Research in Science Teaching, 54(3), 379-411.

Duncan-Andrade, J., \& Morrell, E. (2008). The art of critical pedagogy: Possibilities for moving from theory to practice in urban schools. Peter Lang.

Ellis, C., Adams, T. E., Bochner, A. P. (2011). Autoethnography: an overview. Forum Qualitative Sozialforschung / Forum: Qualitative Social Research, 12(1), Art. 10 
Emdin, C. (2011). Citizenship and social justice in urban science education. International Journal of Qualitative Studies in Education, 24(3), 285-301.

Engel, A., Lucido, K., \& Cook, K. (2018). Rethinking narrative: Leveraging storytelling for science learning. Childhood Education, 94(6), 4-12.

Fraenkel, J. R., Wallen, N. E., \& Hyun, H. H. (2012). How to design and evaluate research In education (8th ed.). New York: Mc Graw Hill.

Freire, P. (1970). Pedagogy of the oppressed. Continuum.

Freire, P., \& Macedo, D. P. (1987). Literacy: reading the word and the world. Bergin \& Garvey.

Forber-Pratt, A. J. (2015). "You're Going to Do What?" Challenges of Autoethnography in the Academy. Qualitative Inquiry, 21(9), 821-835. https://doi.org/10.1177/1077800415574908.

Fuentes, A. (2021). "On the Races of Man": Race, racism, science, and hope. In J. Desilva \& J. Browne (Eds.), A most interesting problem: What Darwin's descent of man got right and wrong about human evolution (pp. 144-161). Princeton University Press.

Gay, G. (2002). Preparing for culturally responsive teaching. Journal of Teacher Education, 53(2), 106-116.

Giroux, H. A. (2004). Public pedagogy and the politics of neo-liberalism: Making the political more pedagogical. Policy Futures in Education, 2(3-4), 494-503.

Gould, S. J. (1996). The mismeasure of man. Norton \& Company.

Graham, D., Green, A., Murphy, C., Richards, P. (2019, May 20). An oral history of Trump's bigotry. Retrieved May 29, 2020, from https:/www.theatlantic.com/magazine/archive/2019/06/trump-racism-comments/588067/

Graves, J. L., \& Goodman, A. (2021). Everything you wanted to know about race: But were afraid to ask. Columbia University Press.

Hadzigeorgiou, Y. (2016). Narrative thinking and storytelling in science education. In Y. Hadzigeorgiou (Ed.), Imaginative science education (pp. 83-119). Springer.

Hammond, Z. (2015). Culturally responsive teaching and the brain: promoting authentic engagement and rigor among culturally and linguistically diverse students. Corwin.

HHMI. (2020, May 14). The Biology of Skin Color. Retrieved September 30, 2020, from https://www. biointeractive.org/classroom-resources/biology-skin-color

Jetha, M. K., \& Segalowitz, S. J. (2012). Adolescent brain development: Implications for behavior. Elsevier.

Kendi, I. X. (2019). How to be an antiracist (1st ed.). One World.

Klassen, S. (2009). The construction and analysis of a science story: A proposed methodology. Science \& Education, 18, 401-423.

Ladson-Billings, G. (1994). The dreamkeepers. Jossey-Bass Publishing Co.

Lakhani, N. (2019, October 21). 'Racism dictates who gets dumped on': how environmental injustice divides the world. Retrieved June 10, 2020, from https://www.theguardian.com/environment/2019/ oct/21/what-is-environmental-injustice-and-why-is-the-guardian-covering-it

Lave, J., \& Wegner, E. (1991). Situated learning. Legitimate peripheral participation. Cambridge University Press.

Lewontin, R. C. (1991). Biology as ideology. New York: HarperCollins.

Lin-Siegler, X., Ahn, J., Chen J., Fang, F., Luna-Lucero, M. (2017). Stories of struggle teaching the value of effort and persistence in science. American Educator, Spring 35-44.

Merriam, S. B. (1992). Qualitative research and case study applications in education. Jossey-Bass.

Merriam, S. B. (2009). Qualitative research: A guide to design and implementation. Wiley, John \& Sons, Incorporated.

Morales-Doyle, D. (2015, October 21). Science education as a catalyst for social change? Justice-centered pedagogy in secondary chemistry. (Doctoral Dissertation). University of Illinois at Chicago. https://indigo.uic.edu/articles/Science_Education_as_a_Catalyst_for_Social_Change_Justice-Cente red_Pedagogy_in_Secondary_Chemistry/10896803/1

Morales-Doyle, D. (2017). Justice-centered science pedagogy: A catalyst for academic achievement and social transformation. Science Education, 101, 1034-1060.

National Research Council. (2012). A framework for K-12 science education: Practices, crosscutting concepts, and core ideas. The National Academies Press.

NGSS Introduction and Overview. (2013). Retrieved November 23, 2019, from https://www.nextgensci ence.org/resources/ngss-introduction-and-overview

Olitsky, S., \& Milne, C. (2012). Understanding engagement in science education: The psychological and the social. In B. J. Fraser, K. Tobin, \& J. McRobbie (Eds.), 2nd International handbook of science education (pp. 19-33). Springer Publishing.

Patton, M. (2015). Qualitative research \& evaluation methods (4th ed.). Sage. 
Petrella, C., \& Hasan Loggins, A. (2017, January 08). "This is a Country for White Men": White Supremacy and U.S. Politics. Retrieved September 07, 2020, from https://www.aaihs.org/this-is-acountry-for-white-men-white-supremacy-and-u-s-politics/

Prilleltensky, I., \& Gonick, L. (1996). Polities change, oppression remains: On the psychology and politics of oppression. Political Psychology, 17(1), 127-148.

Questbrige, about. (2020). Retrieved May 30, 2020, from https://www.questbridge.org/about

Reid-Smith, J.A. (2013). Historical short stories as nature of science instruction in secondary science classrooms: science teachers' implementation and students' reactions. (Doctoral dissertation). Iowa State University.

Reiss, M. J. (2003). Science education for social justice. In C. Vincent (Ed.), Social justice, education and identity (pp. 153-164). RoutledgeFalmer.

Rodriguez, A. J. (1998). Strategies for counterresistance: Toward sociotransformative constructivism and learning to teach science for diversity and for understanding. Journal of Research in Science Teaching, 35(6), 589-622.

Rudge, D. W., Cassidy, D. P., Fulford, J. M., \& Howe, E. M. (2014). Changes observed in views of nature of science during a historically based unit. Science \& Education., 23, 1879-1909.

Sadler, T. D. (2009). Situated learning in science education: Socio-scientific issues as contexts for practice. Studies in Science Education, 45(1), 1-42.

Saldaña, J., \& Omasta, M. (2018). Qualitative research: Analyzing life. Thousand Oaks, CA: SAGE Publications.

Saini, A. (2019). Superior: The return of race science. Beacon Press.

Seiler, G., \& Gonsalves, A. (2010). Student-powered science: Science education for and by African American students. Equity \& Excellence in Education, 43(1), 88-104.

Southern Poverty Law Center. (2020). Social justice standards. Retrieved May 29, 2020, from https://www. tolerance.org/frameworks/social-justice-standards

Stake, R. E. (2006). Multiple case study analysis. The Guilford Press.

Starr, L. J. (2010). The use of autoethnography in educational research: Locating who we are in what we do. Canadian Journal for New Scholars in Education, 3(1), 1-9.

Thompson, M., Beckwith, J., \& Stevens-Truss, R. (2014, March 1). Teaching science and social justice. Retrieved June 13, 2020, from https://www.asbmb.org/asbmb-today/opinions/030114/teaching-scien ce-and-social-justice

Tollefson, J. (2020). How Trump damaged science — and why it could take decades to recover. Nature, 586, 190-194. https://doi.org/10.1038/d41586-020-02800-9

United Nations. (1948). Universal declaration of human rights. Retrieved July 02, 2020, from www.un.org/ en/universal-declaration-human-rights/

United Nations. (2006). Social justice in an open world: the role of the United Nations. Retrieved July 02, 2020, from https://www.un.org/esa/socdev/documents/ifsd/SocialJustice.pdf

Williamson, V., \& Gelfand, I. (2019, August 13). Trump and racism: what do the data say? Retrieved May 29, 2020, from https://www.brookings.edu/blog/fixgov/2019/08/14/ trump-and-racism-what-do-the-data-say/

Yin, R. K. (2018). Case study research and applications: design and methods (6th ed.). Thousand Oaks, CA: Sage Publications.

Publisher's Note Springer Nature remains neutral with regard to jurisdictional claims in published maps and institutional affiliations. 